\title{
KONTRIBUSI SYAIR ACHMAD SYAUQI BAGI PERKEMBANGAN ANAK
}

\author{
Annisa Mutiara Rj \\ annisa.mutiara.rj@gmail.com \\ Eva Farhah \\ hawafarhah@yahoo.com \\ Program Studi Sastra Arab Fakultas Ilmu Budaya \\ Universitas Sebelas Maret Surakarta
}

\begin{abstract}
This research tries to find the text structure and also the personal and educational values of a children poem by Achmad Syauqi (1868-1932 M) entitled "Sulaimān wathThäwüs". The theory used is Michael Riffaterre's semiotic. It is a discipline which studies system, rules, and conversions which enables to see the meaning of the sign. The method used is descriptive qualitative, which explains data in form of word, phrases, sentences, or expressions in the text. Not only that this research also reveals the personal and educational values of the text. In this case the purpose of this research is first, to explain the poem's text structure and second, to reveal the personal and educational values as contribution to children poems. It is found that the text structure of "Sulaimān wath-Thäwis" has a single relation between elements so it gives a clear meaning. The personal and educational values given in the text "Sulaimān wath-Thäwüs" includes emotional growth, intelligent, imaginations, ethical and religious growth, exploration, language, aesthetic values and reading habit.
\end{abstract}

Keywords: Value, Personal, Education, Sulaimān wath-Thāwūs, Semiotic.

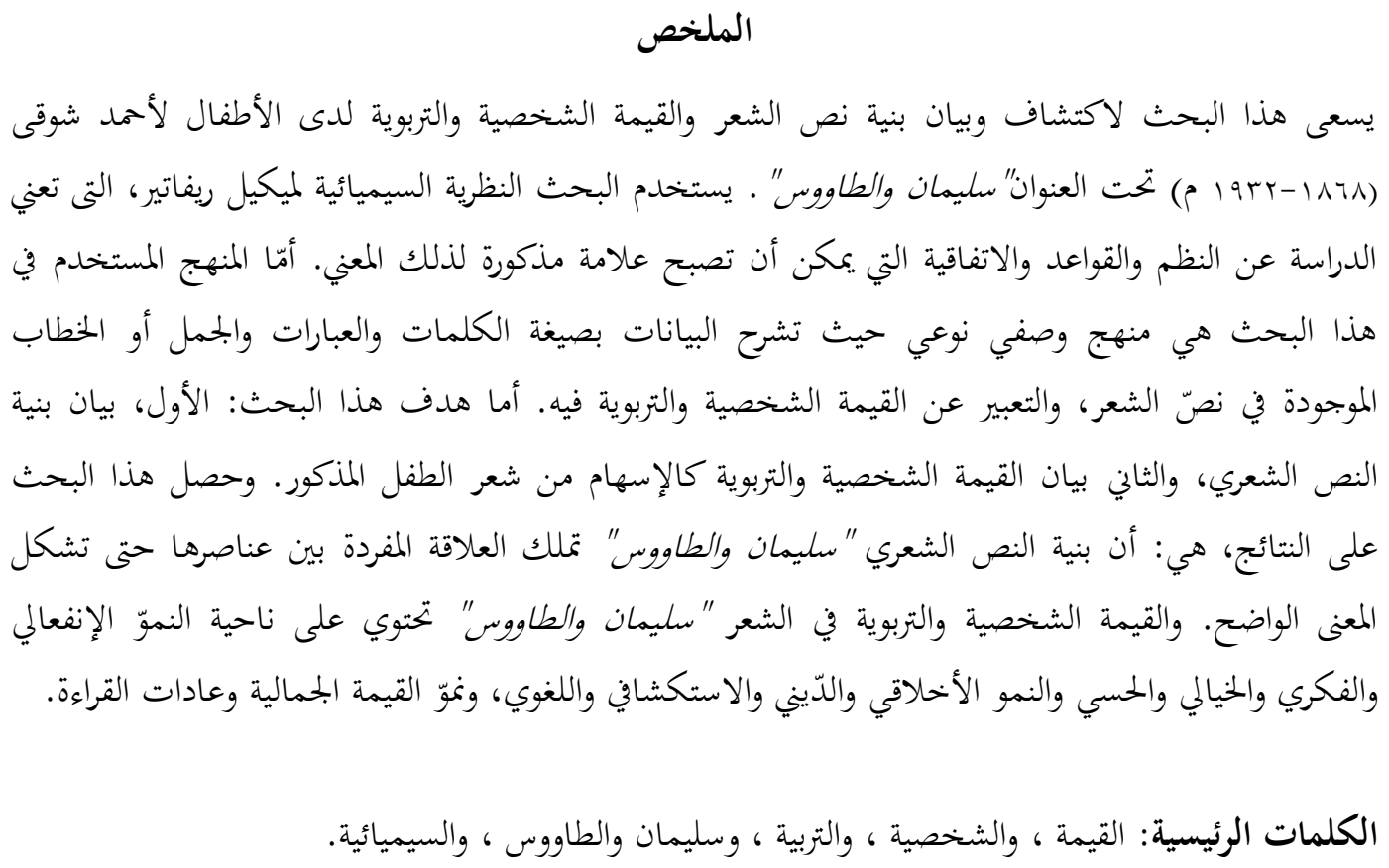




\section{PENDAHULUAN}

Karya sastra memberikan kontribusi bagi perkembangan anak (Saxby dan Winch, dalam Nurgiyantoro, 2013:36). Salah satu karya sastra yang mudah diapresiasi oleh semua kelompok pembaca, baik anak-anak maupun pembaca dewasa yaitu syair, khususnya syair anak. Syair anak dapat dipahami sebagai sesuatu yang merujuk kepada bahasa, isi, dan tipografi yang telah disesuaikan dengan perkembangan pengetahuan dan wawasan anak serta perasaan anak yang masih terbilang sederhana (Kurniawan, 2009:28).

Salah satu penyair sekaligus penulis syair anak dalam sastra Arab adalah Achmad Syauqi. Syair yang diteliti dalam artikel ini berjudul "Sulaimān wathThầüs", yaitu syair yang memiliki tema tentang larangan untuk sombong karena setiap makhluk hidup memiliki keistimewaan masing-masing. Dengan demikian, pembahasan dalam penelitian ini mencakup: (1) Bagaimana struktur syair Arab anak yang berjudul "Sulaimān wath-Thäwūs" karya Achmad Syauqi serta pemaknaannya berdasarkan teori semiotika Michael Riffatere?, (2) Apa saja kontribusi syair Arab anak yang berjudul "Sulaimān wath-Thāwūs" karya Achmad Syauqi bagi anak atau pembaca?

Tujuan penelitian ini adalah: (1)Menjelaskan dan mendeskripsikan struktur syair Arab anak yang berjudul "Sulaimān wath-Thāwüs" karya Achmad Syauqi serta pemaknaannya berdasarkan semiotika Michael Riffatere, (2) Mengungkapkan kontribusi syair Arab anak yang berjudul "Sulaimān wathThāwüs" karya Achmad Syauqi bagi anak atau pembaca. Penelitian tentang struktur teks dan nilai personal serta pendidikan yang terdapat di dalam teks syair "Sulaimān wath-Thāwüs", dengan memanfaatkan teori semiotika Michael Riffaterre, berdasarkan penelusuran tinjauan pustaka belum pernah dilakukan oleh peneliti sebelumnya.
Teori yang digunakan sebagai pisau analisis dalam penelitian ini adalah teori semiotika Michael Riffatere. Prinsip kerja teori ini ada 5 (lima) yaitu, a) ketidaklangsungan ekspresi, b) pembacaan heuristik, c) pembacaan hermeneutik (retroaktif), d) menentukan matriks atau kata kunci, e) menentukan hipogram. Lima prinsip kerja yang dikemukakan oleh Riffatere tersebut hanya empat prinsip kerja yang digunakan dalam penelitian ini, yaitu, a) pembacaan heuristik, b) pembacaan hermeneutik (retroaktif), c) menentukan matriks atau kata kunci, d) menentukan hipogram.

\section{Pembacaan Heuristik}

Pembacaan heuristik atau heuristic reading merupakan penafsiran tahap pertama. Pada tahap pembacaan ini membutuhkan suatu kompetensi atau pengetahuan pembaca dalam lingkup linguistik, karena suatu bahasa mencakup atau memiliki arti yang referensial (satu kata merujuk pada satu hal lain) dan pada tahap ini kata-kata terlihat saling berhubungan. Pada tahap pembacaan ini juga dibutuhkan kompetensi atau pengetahuan pembaca untuk merasakan "incompatibilities between words" (ketidaksesuaian antar kata) salah satunya untuk mengidentifikasi kata yang bersifat metafora dan kata atau frasa yang tidak mengacu pada makna harfiah (makna asli). Oleh karena itu, seorang pembaca harus melakukan "semantic transfer" atau pemindahan makna agar kata bisa dipahami (Riffatere, 1978:5).

Proses atau tahap pembacaan heuristik pada penelitian ini dapat melalui tahap-tahap berikut: 1) membaca keseluhuran teks syair-syair anak berbahasa Arab karya Achmad Syauqiyang dijadikan objek penelitian secara struktur teks dan konvensi bahasa Arab, 2) keseluhuran teks syair-syair anak berbahasa Arab karya Achmad Syauqiyang dijadikan objek penelitian ditransliterasikan ke dalam bahasa latin, 3) tahap penyesuaian atau tahap akhir dari 
proses pembacaan heuristik atau heuristic reading. Pada tahap ini keseluruhan teks syair-syair anak berbahasa Arab Achmad Syauqiyang sudah dibaca secara struktur teks dan konvensi bahasa Arab serta sudah ditransliterasi ke dalam bahasa latin, selanjutnya disesuaikan dengan terjemahan bahasa Indonesia. Secara keseluruhan setelah melakukan ketiga proses tersebut akan ditemukan makna utuh dari setiap syair-syair anak karya Achmad Syauqiyang dijadikan objek penelitian.

\section{Pembacaan Hermeneutik}

Tahap kedua adalah pembacaan retroaktif (pembacaan ulang). Pembacaan ini adalah sebagai tahap penafsiran kedua, yaitu untuk pembacaan hermenutik yang sebenarnya. Pada tahap ini seorang pembaca melakukan pembacaan teks secara berulang, mengingat semua teks yang sudah dibaca kemudian akan dimodifikasi atau ditafsirkan sesuai pemahamannya. Ketika seorang pembaca melakukan pembacaan teks dari awal sampai akhir, dia akan me-review, merevisi, dan membandingkan semua kejadian-kejadian yang dia baca. Fungsi utama pembacaan retroaktif, yaitu sebagai "generator of significance" (pembuat makna), dan makna tersebut akan didapat di bagian akhir sebuah puisi atau syair (Riffatere, 1978: 5-6).

\section{Matriks}

Matriks merupakan hipotesis atau pernyataan sementara, yang diaktualisasikan dalam bentuk grammar dan leksikal dari sebuah struktur. Matriks juga dilambangkan dalam suatu kata, dan kata tersebut tidak muncul dalam teks. Akan tetapi selalu diaktualisasikan dalam bentuk varian yang berturut-turut; bentuk varian ini ditentukan dari wujud aktualisasi pertama, yaitu model. Matriks, model, dan teks merupakan bentuk varian dari struktur yang sama (Riffatere, 1978:19).

\section{METODELOGI PENELITIAN}

Penelitian sastra ini menggunakan metode deskriptif, yaitu metode yang menggunakan prosedur pemecahan masalah yang diselidiki dengan menggambarkan keadaan subjek atau objek penelitian (novel, drama, cerita pendek, puisi) pada saat sekarang berdasarkan fakta-fakta sebagaimana adanya (Siswantoro, 2014:56). Sedangkan teknik penelitian yang dimanfaatkan dalam penelitian ini adalah sebagai berikut:

1. Teknik penentuan data

Teknik ini dapat didefinisikan sebagai sesuatu yang terkait dengan pencarian dan pemilihan objek yang akan diteliti yang biasanya mencakup selera penulis, dalam hal ini syair-syair Arab anak karya Achmad syauqi

2. Teknik pengumpulan data

Teknik pengumpulan data dalam penelitian ini meliputi membaca, menerjemahkan, memahami, memaknai, dan mengkategorikan syair Arab anak karya Achmad Syauqi yang dijadikan objek penelitian dengan cara melihat struktur dan isi teks syair

3. Teknik penentuan metode

Teknik penentuan metode dianggap perlu karena sebagai syarat utama dalam penelitian untuk memudahkan dalam tahap penganalisisan. Dalam penelitian ini metode yang digunakan adalah dengan memanfaatkan semiotika Michael Riffaterre yang melengkapi dan menunjang penelitian.

4. Teknis analisis data

Berdasarkan objek dan penentuan metode yang sudah dipilih maka tahap analisisnya dapat dirinci sebagai berikut:

Pertama, memanfaatkan cara pembacaan heuristik untuk memberikan makna teks syair. Pada tahap ini akan ditemukan pemahaman makna karya sastra secara harfiah (Riffaterre, 1978:5). Kedua, pembacaan hermeneutik dalam syair, cara membacanya dengan membolak-balik dari awal hingga akhir teks syair untuk memudahkan mengingat 
kejadian atau peristiwa di dalam teks syair yang baru dibaca (Sangidu, 2004:19). Selain itu, untuk menentukan makna syair yang hendak disampaikan atau dimaksud penulis karya sastra (syair) tersebut. Ketiga, menentukan matriks atau kata kunci sebagai cara untuk mengantarkan karya sastra (syair) supaya mudah untuk dipahami. Keempat, menentukan hipogram yaitu menemukan dan menafsirkan respon dari karya sastra yang baru setelah dibandingkan dengan teks atau karya sastra yang menjadi latar penciptaannya. Kelima, menganalisis dan mengungkap nilai-nilai yang ada pada objek penelitian (syair Arab anak) karya Achmad Syauqi seperti nilai personal dan pendidikan supaya dapat mengungkapkan kontribusinya bagi anak atau pembaca.

\section{PEMBAHASAN}

1. Pembacaan Heuristik

Salah satunya yaitu syair ke-3, dengan deskripsi dan uraian sebagai berikut:

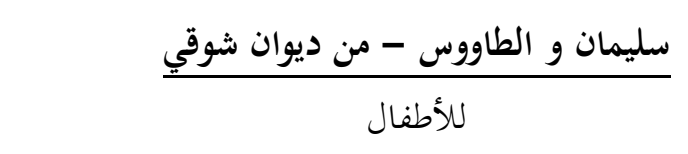

[Sulaimān wath-Thāwus-min Diwān Syauqi lil Athfäl]

Sulaiman dan Seekor Merak-dari Syair

Syauqi untuk Anak-anak

$$
\text { سمعتُ بأنّ طاووساً }
$$

[Sami 'tu bi'anna thāwūsan]

Suatu hari aku mendengar burung Merak

$$
\text { أتى يوماً سليمانا }
$$

[Atā yauman sulaimānā]

Menghadap pada Sulaiman

$$
\text { يجررُ دون وفِدِ الطيْرِ أذيالاً وأردانا }
$$

[Yujariru dūna wafdith-thairi adzyālan wa ardānan]

Dia menghadap tanpa utusan burung dan membentangkan ekornya

$$
\text { ويظهرُ ريشهُ طوراً }
$$

[Wa yadhharu raisyahu thauran]

Sebagai burung dia tampakan bulunya

$$
\text { ويخفي الريشَ أحيانا }
$$

[Wa yukhfi ar-raisya achyānan]

Dan terkadang bulu itu dia sembunyikan

$$
\text { فقال: لديَّ مسألةُ }
$$

[Fa qāla: ladayya mas'alatun]

Dia berkata: aku memiliki masalah

$$
\text { أظنٌُ أواها آنا }
$$

\section{[Adzunnu awānuhā ānā]}

Inilah waktuku

$$
\text { وها قد جئت أعرضها }
$$

[Wa hà qad ji'tu u'ridhuhā]

Dan inilah aku datang menentangnya

$$
\begin{gathered}
\text { على أعتابِ مولانا: } \\
\text { ['Ala a'tābi maulānāa.] }
\end{gathered}
$$

Untuk mencela Tuan kami:

$$
\begin{gathered}
\text { ألستُ الروضَ بالأزها } \\
\text { [Alastu ar-raudha bil azhā] }
\end{gathered}
$$

Bukankah aku adalah sebuah taman penuh bunga

$$
\text { رِ والأنوارِ مزدانا؟ }
$$

[-ri wal anwāri mazdānā]

Dan penuh dengan perhiasan cahaya?

$$
\text { ألم أستوفِ آيَ الظرفف أشكالاً وألوانا؟ }
$$

[Alam astaufi àya adz-dzarfi asykālan wa alwānan?]

Bukankah aku sudah memenuhi semua itu dengan bentuk dan warnaku?

$$
\text { ألم أصبح ببابكمُ }
$$


[Alam ushbich bibābikum]

Tak pantaskah aku menjadi pemimpin di pintumu

$$
\text { لجمعِ الطيرِ سلطانا؟ }
$$

[Lijam 'i ath-thairi sulthāna?]

Untuk semua burung?

$$
\text { فكيف يليقُ أن أبقى }
$$

[Fa kaifa yaliqu an abqā]

Dan bagaimana aku menetapkan

$$
\text { وقومي الغرُّ أوثانا؟ }
$$

[Wa qaumī al-gharru autsānā]

Sementara kaumku menuhankan Gharru?

$$
\begin{gathered}
\text { فحسنُ الصوتِ قد أمسىى } \\
\text { [Fachusnu ash-shauti qad amsā] } \\
\text { Maka suara indah itu menjadi }
\end{gathered}
$$

$$
\text { نصيبي منه حرمانا }
$$

[Nashībì minhu churmānā]

diharamkan atas nasibku

$$
\text { فما تيَّمتتُ أفئدةً }
$$

[Famā tayyamtu af'idatan]

Yang tak mampu melenakan hati

$$
\text { ولا أسكرتُ آذانا }
$$

[Wa là askartu ādzānā]

Dan tak mampu memabukan pendengaran

$$
\text { وهذي الطير أحقرها }
$$

[Wa Hàdzì ath-thairu achqaruhā]

Burung inilah yang paling buruk

$$
\text { يزيدُ الصبَّ أشجانا }
$$

[Yazīdu ash-shabba asyjānā]

Dan rindu itu bertambah menjadi nestapa

$$
\text { وتهتزُّ الملوكُك له }
$$

[Wa tahtazzu almulūku lahu]

Dia menggoncang para raja

$$
\begin{gathered}
\text { إذا ما هنَّ عيدانا؟ } \\
\text { [Idzā mā hazza ìdānā] }
\end{gathered}
$$

Mengapa tak menggoncang musuh kita?

$$
\text { فقال له سليمانُ }
$$

[Fa qāla lahu sulaimānu]

Sulaiman pun berkata padanya

$$
\begin{gathered}
\text { لقد كان الذي كانا } \\
\text { [Laqad kāna alladzī kāna] }
\end{gathered}
$$

Yang telah terjadi maka terjadilah

$$
\begin{aligned}
& \text { تعالت حكمةُ الباري } \\
& \text { [Ta'ālat chikmatu albārīi] }
\end{aligned}
$$

Maha tinggi keadilan sang pencipta

$$
\begin{gathered}
\text { وجلَّ صنيعُُ شانا } \\
\text { [Wa jalla shanī uhu syānā] }
\end{gathered}
$$

Maha mulia takdir yang ditentukannya

$$
\text { لقد صغرتَ يا مغرو }
$$

[Laqad shaghurta yā maghrū]

Kau telah mengecil wahai burung yang angkuh

$$
\text { رُ نعمى الله كفرانا }
$$

[-ru ni mal-lāhi kufrānā]

Atas nikmat Allah sebagai burung yang kafir

$$
\text { وملك الطير لم تحفل }
$$

[Wa maliku ath-thairi lam tachafala]

Raja burung itu tidaklah kufur

$$
\text { به، كبرا وطغيانا }
$$

[Bihi, kubran wa tughyānā] 
Sebagai burung yang sombong dan sewenang- wenang

$$
\text { فلو أصبحتَ ذا صوت }
$$

[Fa lau ashbachta dzā shautin]

Andai engkau sebagai burung yang memiliki suara

$$
\text { با كلمتَ إنسانا }
$$

\section{[Limā kallamta insānā]}

Kau tak akan mampu berbincang dengan manusia

(Syauqī, dalam Muntadi Syabāb Al-Mathariyah, 2012:2-4).

2. Pembacaan Hermeneutik

Pembacaan hermeneutik syair ke-3 yaitu:

Syair ke-3 yang berjudul "Sulaimān wath-Thäwūs" artinya 'Sulaiman dan Seekor Merak'.Burung Merak tersebut memiliki sifat angkuh atau sombong. Keangkuhan sebagai sifat dari Merak tersebut dapat dilihat pada kutipan berikut:

$$
\begin{aligned}
& \text { يجررٌ دون وفِد الطيْرِ أذيالاً وأردانا. } \\
& \text { [Yujariru dūna wafdith-thairi } \\
& \text { adzyālan wa ardānan]. } \\
& \text { Dia menghadap tanpa utusan }
\end{aligned}
$$
burung dan membentangkan ekornya. (Syauqii, dalam Muntadi Syabāb Al-Mathariyah, 2012:2).

Burung Merak datang menghadap Nabi Sulaiman karena dia tidak menerima jika burung lain yang menjadi pemimpin para burung. Burung yang dimaksud yaitu Gharru. Gharru adalah sejenis burung yang memiliki suara indah. Dia ditetapkan sebagai pemimpin para burung oleh Nabi Sulaiman.

Keangkuhan sebagai sifat Merak yang dikisahkan dalam syair "Sulaimān wath-Thâwūs" sebagaimana pula halnya yang dikemukakan oleh Kurniawan (2001:176) bahwa Merak merupakan makhluk yang tidak ada apa-apanya. Dia selalu membangga-banggakan dirinya tanpa pembenaran yang dipahami. Selain sifatnya yang angkuh dan tidak memiliki kesopanan, Merak juga burung yang tidak bersyukur atas nikmat Allah yang telah ditentukan untuknya hingga menjadikannya sebagai burung yang kufur. Jika saja Merak yang angkuh itu memiliki keindahan suara, maka untuk berbicara kepada seorang manusia bahkan kepada Nabi Sulaiman sebagai utusan Allah sekaligus sebagai seorang raja dan pemimpin besar semua hewan tidak akan bisa dia lakukan. Sebagaimana kutipan berikut:

$$
\begin{aligned}
& \text { وملك الطير لم تحفل/ } \\
& \text { به، كبرا وطغيانا/ } \\
& \text { فلو أصبحتَ ذا صوت } \\
& \text { لما كلمتَ إنسانا. } \\
& \text { [Wa maliku ath-thairi lam } \\
& \text { tachafalal }
\end{aligned}
$$

\section{Matriks}

Setelah melakukan tahap pembacaan heuristik, dan pembacaan hermeneutik, tahap selanjutnya adalah menentukan matriks atau kata kunci. Matriks atau kata kunci dapat berupa kata, frasa, ataupun kalimat. Dengan demikian dapat diketahui bahwa, matriks dari syair 
ke-3 adalah burung Merak, burung Gharru, dan Nabi Sulaiman.

\section{Kontribusi Sastra Anak}

Adapun, kontribusi sastra anak yang terdapat dalam kisah syair ke-3 yaitu:

a. Aspek Perkembangan Emosional

Emosi positif dapat menunjang keberhasilan anak dalam melakukan aktivitasnya. Sebaliknya jika anak memiliki emosi negatif, maka akan menjadi penghalang terhadap pertumbuhan anak, baik yang berhubungan dengan sikap mental anak ataupun aktivitas lainnya. Oleh karena itu, bentuk emosi negatif sebaiknya tidak diterapkan pada diri anak.

Tokoh yang terdapat dalam kisah syair "Sulaimān wath-Thâwūs" memberikan perumpamaan bentuk emosi negatif yaitu berupa sifat iri hati yang dimiliki burung Merak atas dipilihnya Gharru oleh Nabi Sulaiman sebagai pemimpin burung. Hal demikian tampak pada kutipan berikut:

$$
\begin{aligned}
& \text { ألم أستوفِ آيَ الظرُف أشكالاً وألوانا؟/ }
\end{aligned}
$$

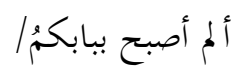

$$
\begin{aligned}
& \text { لجمع الطيرٍ سلطانا؟. }
\end{aligned}
$$

[Alam astaufi àya adz-dzarfi asykālan wa alwānan?/

Alam ushbich bibābikum/Lijam'i ath-thairi sulthāna?].

Bukankah aku sudah memenuhi semua itu dengan bentuk dan warnaku?/

Tak pantaskah aku menjadi pemimpin di pintumu/ Untuk semua burung?.

(Syauqī, dalam Muntadi Syabāb AlMathariyah, 2012:3).

Ungkapan Merak yang menandakan rasa iri hatinya terhadap Gharru dapat menjadikan pembelajaran sekaligus penyampaian pendidikan karaker kepada anak, bahwa memiliki jiwa yang positif adalah salah satu modal yang sehat untuk menjadikan kehidupan yang lebih tenang dan bahagia, salah satunya supaya terhindar dari sifat iri hati.

\section{b. Aspek Perkembangan Intelektual}

Berdasarkan hasil pemahamannya setelah diceritakan atau membaca sendiri jika sudah bisa, anak akan mengidentifikasi tentang mana tokoh baik dan mana tokoh jahat, menilai mana perbuatan yang pantas ditiru dan tidak (Musfiroh, 2008:62). Hal tersebut sebagaimana kisah yang terdapat dalam syair "Sulaimān wath-Thāwūs".

Pertama, anak akan mengidentifikasi tentang tokoh yang ada dalam syair "Sulaimān wath-Thāwūs". Setelah membaca atau dibacakan, anak akan mengetahui tentang Merak yang angkuh, tentang Gharru yang ditetapkan sebagai pemimpin para burung karena memiliki suara yang indah.

Kutipan yang menunjukan sifat Merak yang angkuh yaitu:

$$
\begin{aligned}
& \text { يجررُ دون وفدِ الطيْرِ أذيالاً وأردانا. } \\
& \text { [Yujariru dūna wafdith-thairi } \\
& \text { adzyālan wa ardānan]. } \\
& \text { Dia menghadap tanpa utusan }
\end{aligned}
$$
burung dan membentangkan ekornya. (Syauqi, dalam Muntadi Syabāb Al-Mathariyah, 2012:2).

Kutipan yang menunjukan bahwa Gharru adalah burung yang memiliki keindahan suara dan menjadi pemimpin burung yaitu:

$$
\begin{aligned}
& \text { وقومي الغرّ أوثانا؟/ } \\
& \text { فحسنُ الصوتِ قد أمسى } \\
& \text { نصيبي منه حرمانا. }
\end{aligned}
$$


diharamkan atas nasibku.

(Syauqi, dalam Muntadi

Syabāb Al-Mathariyah, 2012:3).

Kedua, anak akan menilai tentang perbuatan ataupun sifat yang pantas ditiru dan tidak. Sebagai perumpamaan adalah sifat Merak yang angkuh. Karena angkuh atau sombong merupakan sifat yang terlalu membesarkan atau mengagungkan terhadap sesuatu yang dimiliki (Dhaif, 2004:773). Anak akan menilai bahwa sifat tersebut tidak pantas untuk ditiru karena terlalu mengagungkan sesuatu yang dimiliki menimbulkan pandangan rendah kepada orang lain dan pandangan tersebut sama halnya dengan tidak menghargai keistimewaan yang dimiliki oleh masingmasing makhluk.

\section{c. Aspek Perkembangan Imajinasi}

Kisah syair ke-3 "Sulaimān wathThāwüs" memberikan ruang imajinasi kepada anak tentang Nabi Sulaiman dan Merak. Merak adalah burung yang memiliki keindahan bentuk dan warna, sebagaimana yang disebutkan dalam kutipan berikut:

$$
\text { ألستُ الروضَ بالأزها/ }
$$

[Alastu ar-raudha bil azhäa -ri wal anwāri mazdānā].

Bukankah aku adalah sebuah taman penuh bunga/

Dan penuh dengan perhiasan cahaya?

(Syauqī, dalam Muntadi Syabāb AlMathariyah, 2012:3).

Namun, keindahan Merak hanya sebatas fisiknya. Merak itu sombong dan tidak memiliki sikap yang santun. Hal itu terbukti saat Merak menemui Nabi Sulaiman tanpa utusan burung dan dia membentangkan ekor dan memamerkan bulu-bulunya. Kutipan yang menunjukan sikap dan kesombongan Merak yaitu:

$$
\begin{aligned}
& \text { يجررُ دون وفِد الطيْرِ أذيالاً وأردانا/ } \\
& \text { ويظهرُ ريشهُ طوراً. }
\end{aligned}
$$

[Yujariru dūna wafdith-thairi adzyālan wa ardānan/

Wa yadhharu raisyahu thauran].

Dia menghadap tanpa utusan

burung dan membentangkan ekornya/

Sebagai burung dia tampakan bulunya.

(Syauqui, dalam Muntadi Syabāb Al-

Mathariyah, 2012:2).

Melalui daya imajinasi anak akan memperoleh pemahaman baru bahwa keindahan fisik harus dibarengi dengan perilaku yang baik. Bukan seperti Merak yang hanya membangga-banggakan dirinya tanpa pembenaran yang dipahami (Kurniawan, 2001:176).

d. Aspek Pertumbuhan Rasa Etis dan Religius

1) Makhluk dengan Makhluk

Hubungan makhluk dengan makhluk yaitu hubungan Merak dan Nabi Sulaiman kaitannya dengan etika. Adapun, dalam kisah syair "Sulaimān wath-Thâwüs" ilustrasi yang menjadi perumpamaan adalah sikap Merak yang tidak memiliki etika santun saat menemui Tuannya yaitu Nabi Sulaiman. Kutipan yang menunjukan etika tidak santun Merak adalah:

$$
\begin{aligned}
& \text { يجررُ دون وفدِ الطيْرِ أذيالاً وأردانا/ } \\
& \text { ويظهرُ ريشهُ طوراً. }
\end{aligned}
$$

[Yujariru dūna wafdith-thairi adzyālan wa ardānan/

Wa yadhharu raisyahu thauran].

Dia menghadap tanpa utusan burung dan membentangkan ekornya/

Sebagai burung dia tampakan bulunya.

(Syauqī, dalam Muntadi Syabāb AlMathariyah, 2012:2). 
Sikap yang diilustrasikan oleh seekor Merak dapat sebagai pembelajaran bagi kehidupan anak, bahwa jika anak akan menemui seseorang, misalnya teman sebaya, ataupun orang lain harus dibiasakan memberitahu terlebih dahulu. Selain sebagai bentuk kesopanan saat sebelum berkunjung, hal tersebut juga sebagai bentuk penanaman pendidikan etika berkomunikasi yang baik.

2) Makhluk dengan Tuhan

Makhluk dengan Tuhan dalam kisah syair ke-3 yaitu hubungan antara Merak dan Tuhan. Hal tersebut terkait dengan sifat Merak yang tidak mempercayai terhadap nikmat atau ketentuan yang diberikan Allah. Dia adalah makhluk yang tidak bersyukur atas nikmat yang telah diberikan kepadanya. Sifat Merak teresbut sebagaimana yang diungkapkan oleh Nabi Sulaiman sebagai nasehatnya kepada Merak dalam kutipan berikut:

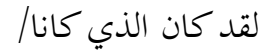

$$
\begin{aligned}
& \text { تعالت حكمةُ الباري| } \\
& \text { وجلَّ صنيعهُ شانا/ } \\
& \text { لقد صغرتَ يا مغرو/ } \\
& \text { رُ نعمى الله كفرانا/ }
\end{aligned}
$$

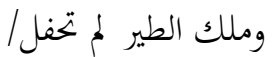

$$
\begin{aligned}
& \text { به، كبرا وطغيانا. } \\
& \text { [Laqad kāna alladzì kāna/ } \\
& \text { Ta'ālat chikmatu albārī/ } \\
& \text { Wa jalla shanī uhu syānā' } \\
& \text { Laqad shaghurta yā maghrū/ -ru } \\
& \text { ni 'mal-lāhi kufrānā/ } \\
& \text { Wa maliku ath-thairi lam } \\
& \text { tachafalal }
\end{aligned}
$$

Kau telah mengecil wahai burung yang angkuh/

Atas nikmat Allah sebagai burung yang kafir/

Raja burung itu tidaklah kufur/

Sebagai burung yang sombong dan sewenang-wenang.

(Syauqīi, dalam Muntadi Syabāb

Al-Mathariyah, 2012:4).

Ungkapan tersebut merupakan nasehat supaya Merak senantiasa menerima dan bersyukur terhadap nikmat dan ketentuan yang sudah menjadi takdirnya.

e. Aspek Eksplorasi dan Penemuan Aspek eksplorasi dan penemuan kaitannya dengan cara anak dalam menanggapi dan berpikir secara logis dan kristis terhadap peristiwa yang terdapat dalam sebuah cerita ( Nurgiyantoro, 2013:42). Aspek eksplorasi dan penemuan dalam kisah syair ke-3 dapat berupa penyesalan terhadap tindakan yang dilakukan oleh tokoh yang juga berkaitan dengan karakter tokoh tersebut. Hal itu sebagaimana tindakan yang dilakukan oleh Merak dalam kutipan berikut:

$$
\begin{aligned}
& \text { ألستُ الروضَ بالأزها/ } \\
& \text { رِ والأنوارِ مزدانا؟/ }
\end{aligned}
$$

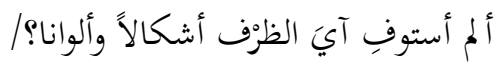

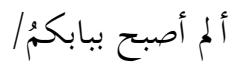

$$
\begin{aligned}
& \text { لجمع الطيرِ سلطانا؟؟ }
\end{aligned}
$$

Bukankah aku adalah sebuah taman penuh bunga/

Dan penuh dengan perhiasan cahaya?/

Bukankah aku sudah memenuhi semua itu dengan bentuk dan warnaku?/ 
Tak pantaskah aku menjadi pemimpin di pintumu/

Untuk semua burung?.

(Syauqī, dalam Muntadi Syabāb AlMathariyah, 2012:3).

Ungkapan yang dikatakan oleh Merak dalam kutipan tersebut memperlihatkan bahwa dia adalah burung yang memiliki kelebihan bentuk dan warna bulunya yang indah. Kutipan tersebut sekaligus memperlihatkan bentuk protes Merak terhadap ketentuan yang sudah ditetapkan oleh Nabi Sulaiman. Selanjutnya, karakter Merak juga dapat dilihat dalam kutipan berikut berupa bentuk nasehat Nabi Sulaiman kepada Merak.

$$
\begin{aligned}
& \text { لق القد كان الذي كانا/ } \\
& \text { تعالت حكمةُ الباري| } \\
& \text { وجلَّ صنيعهُ شانا/ }
\end{aligned}
$$

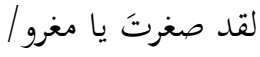

$$
\begin{aligned}
& \text { رُ نعمى الله كفرانا/ }
\end{aligned}
$$

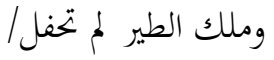

$$
\begin{aligned}
& \text { به، كبرا وطغيانا. } \\
& \text { [Laqad kāna alladzī kāna/ } \\
& \text { Ta'ālat chikmatu albāríl } \\
& \text { Wa jalla shanī uhu syānä/ } \\
& \text { Laqad shaghurta yā maghrū -ru } \\
& \text { ni 'mal-lāhi kufrānàl } \\
& \text { Wa maliku ath-thairi lam } \\
& \text { tachafalal }
\end{aligned}
$$

Sebagai burung yang sombong dan sewenang-wenang.

(Syauqī, dalam Muntadi Syabāb AlMathariyah, 2012:4).

Nasehat Nabi Sulaiman dalam kutipan tersebut memberikan pemahaman kepada pembaca bahwa Merak adalah burung yang angkuh, kufur, dan sewenang-wenang.

Berdasarkan kedua kutipan di atas, dapat menjadi simpulan sebagai point utama dari aspek eklporasi dan penemuan melalui kisah syair ke-3 bagi anak, yaitu anak dapat memahami secara kritis bahwa memiliki kerendahan hati adalah lebih baik dibandingkan harus menyombongkan diri, menerima terhadap keputusan yang sudah menjadi ketetapanNya (belajar memiliki jiwa yang qana'ah), dan tidak berbuat sewenangwenang. Melaui aspek eksplorasi dan penemuan anak akan memahami sekaligus dapat berpikir kritis dalam menilai kejadian ataupun peristiwa dan karakter yang diperankan oleh tokoh cerita.

\section{f. Perkembangan Bahasa}

Aspek perkembangan bahasa yang terdapat dalam keenam syair dipandang dari dua segi. Pertama, segi kontribusi sastra anak yaitu yang berkaitan dengan sastra sebagai karya seni yang bermediakan bahasa dan bahasa itu memegang peranan penting dalam sebuah karya seni. Kedua, segi psikologi perkembangan anak dengan alasan bahwa dalam penelitian ini objek anak yang digunakan adalah anak-anak yang berada dalam tahap elementari akhir, yaitu anakanak yang berusia sepuluh tahun, sebelas tahun, dan dua belas tahun. Anak-anak dengan usia tersebut sudah dapat membedakan kata sebagai simbol, dan konsep yang terkandung dalam kata (Piaget dalam Zuchdi, 2001:7).

\section{g. Pengembangan Nilai Keindahan} Aspek nilai keindahan yang terdapat dalam karya sastra genre syair 
dapat diperoleh melalui rima atau permainan bunyi kata di akhir bait. Kaitannya dengan objek dalam penelitian ini yang menggunakan syair-syair berbahasa Arab, permainan bunyi atau rima tersebut didapat melalui qāfiyah.

Qāfiyah atau qawāfí merupakan huruf yang berada di antara dua huruf yang bersukun di akhir bait ditambah satu huruf sebelum huruf bersukun yang pertama. Yakni, qāfiyah dimulai dari huruf yang berharakat sebelum huruf yang bersukun pertama sampai akhir bait (Imam Khalil, dalam Arifuddin, 2016:2). Berikut ini contoh keindahan bahasa yang diperoleh dari qāfiyah yang terdapat dalam syair ke-3 yaitu:

$$
\begin{aligned}
& \text { سليمان و الطاووس - من ديوان شوقي للأطفال } \\
& \text { سمعتُ بأنّ طاووساً } \\
& \text { أتى يوماً سليمانا } \\
& \text { يجررُ دون وفِِ الطيْرِ أذيالاً وأردانا } \\
& \text { ويظهر ريشهُ طوراً } \\
& \text { ويخفي الريشَ أحيانا } \\
& \text { فقال: لديَّ مسألةُ }
\end{aligned}
$$

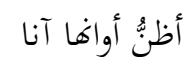

$$
\begin{aligned}
& \text { وها قد جئتُ أعرضها } \\
& \text { على أعتابِ مولانا: } \\
& \text { ألستُ الروضَ بالأزها } \\
& \text { رِ والأنوارِ مزدانا؟ } \\
& \text { ألم أستوفِ آيَ الظرْف أشكالاً وألوانا؟ } \\
& \text { ألم أصبح ببابكمُ } \\
& \text { لجمع الطيرِ سلطانا؟ } \\
& \text { فكيف يليقُ أن أبقى } \\
& \text { وقومي الغرٌٌ أوثانا؟ }
\end{aligned}
$$

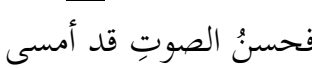

$$
\begin{aligned}
& \text { نصيبي منه حرمانا }
\end{aligned}
$$

$$
\begin{aligned}
& \text { فما تيَّمتُ أفئدةًة } \\
& \text { ولا أسكرتُ آذانا } \\
& \text { وهذي الطير أحقرها } \\
& \text { يزيدُ الصبَّ أشجانا } \\
& \text { وتمتزُّ الملوكُ له له } \\
& \text { إذا ما هزَّ عيدانا؟ } \\
& \text { فقال له سليمانُ } \\
& \text { لقد كان الذي كانا } \\
& \text { تعالت حكمةُ الباري } \\
& \text { وجلَّ صنيعهُ شانا } \\
& \text { لقد صغرتَ يا مغرو } \\
& \text { رُ نعمى الله كفرانا } \\
& \text { وملك الطير لم تحفل } \\
& \text { به، كبرا وطغيانا } \\
& \text { فلو أصبحتَ ذا صوت } \\
& \text { لما كلمتَ إنسانا }
\end{aligned}
$$

(Syauqii, dalam Muntadi Syabāb AlMathariyah, 2012:2-4).

Aspek keindahan bahasa yang terdapat dalam syair ke-3 tersebut dapat sebagai pemenuhan batin anak akan keindahan. Pemenuhan batin dapat diperoleh melalui pembacaan atau pendeklamasian syair-syair tersebut, baik oleh pencerita ataupun anak jika sudah bisa. Keindahan bunyi tersebut akan merangsang jiwa anak untuk tertarik terhadap kisah yang ada dalam teks syair. Hal itu dapat dikatakan sebagai rasa keingintahuannya. Rasa ingin tahu dapat diartikan sebagai modal bagi anak yang menjadi pendukung mereka untuk terus belajar (Farida, 2014:95).

h. Penanaman Kebiasaan Membaca

Bacaan yang memiliki kisah menarik dapat menumbuhkan kecintaan anak terhadap karya sastra. Bacaan tersebut salah satunya melalui kisah syair 
ke- yang berjudul "Sulaimān wathThäwūs". Kecintaan anak terhadap karya sastra dapat meningkatkan hobi dan kesukaan anak pada membaca, yang akhirnya dapat meningkatkan kebiasaan membaca (reading habit) anak. Seorang pencerita yaitu orang tua ataupun guru dapat memberikan pemahaman kepada anak bahwa kebiasaan membaca ini merupakan kunci untuk menguasai ilmu apapun, karena segala ilmu pengetahuan hanya bisa dipelajari dengan membaca (Kurniawan, 2009:2). Selain itu, dengan membaca anak akan mudah memahami sesuatu, mampu mengkaji informasi dengan cepat dan kritis (Farida, 2014:85).

\section{PENUTUP}

Pembacaan heuristik yang
dilakukan terhadap syair ke-3 menghasilkan makna utuh. Makna utuh yang terdapat dalam syair ke-3 berupa larangan untuk sombong karena setiap makhluk memiliki keistimewaan masingmasing. Pembacaan hermeneutik menghasilkan pemahaman tentang karakter burung Merak yang angkuh, kufur, dan sewenang-wenang. Matriks syair ke-3 yaitu burung Merak, Gharru, dan Nabi Sulaiman.

Adapun kontribusi sastra anak yang dihasilkan melalui syair ke-3 yang berjudul "Sulaimān wath-Thâwüs", adalah sebagai berikut:

1. Kontribusi aspek perkembangan emosional: Anak menjadi bersyukur dengan kelebihan yang dimiliki, dan dapat menerima ketentuan yang sudah ditetapkan Allah.

2. Kontribusi aspek perkembangan intelektual: Anak akan mengidentifikasi tentang tokoh cerita dan anak akan menilai tentang perbuatan ataupun sifat yang pantas untuk ditiru dan tidak

3. Kontribusi aspek perkembangan imajinasi: Anak akan memperoleh imajinasi baru bahwa keindahan fisik harus dibarengi dengan perilaku yang baik.

4. Kontribusi aspek pertumbuhan rasa etis dan religius: Anak dapat menyadari akan pentingnya etika (kesantunan) saat berkunjung, baik kepada teman, saudara, ataupun orang lain. Selain itu, anak dapat menjadi pribadi yang senantiasa bersyukur, dapat menghargai nikmat dan ketentuan yang diberikan Allah.

5. Kontribusi aspek eksplorasi dan penemuan: Anak dapat memahami secara kritis bahwa memiliki kerendahan hati adalah lebih baik dibandingkan harus menyombongkan diri, menerima terhadap keputusan yang sudah menjadi ketetapan-Nya (belajar memiliki jiwa yang qana'ah), dan tidak berbuat sewenang-wenang.

6. Aspek perkembangan bahasa: Anak jadi memiliki perbendaharaan kata baru, dan anak jadi memiliki kemampuan berbahasa baik secara aktif reseptif maupun aktif produktif.

7. Aspek pengembangan nilai keindahan: Kebutuhan batin anak akan keindahan terpenuhi, dapat menumbuhkan rasa ingin tahu anak dan membuat anak menjadi senang untuk terus belajar.

8. Aspek kontribusi penanaman kebiasaan membaca: Pertama, bimbingan membaca dengan orang tua atau guru sebagai pemberi arahan atau pemahaman terhadap makna yang terkandung dalam keenam syair tersebut atau karya sastra secara umum. Kedua, kebiasaan membaca akan lebih disukai anak apabila buku ceritanya bergambar. Ketiga, kisah-kisah atau cerita yang baik, maka anak akan tertarik untuk membaca. 


\section{DAFTAR PUSTAKA}

Arifuddin. 2016. Ilmu Qafiyah. Handout matakuliah Arudl waqawafi. Prodi Sastra Arab UNS: Surakarta.

Dhaif, Syauqi. 2004. Al-Mu'jam AlWasith. Mesir: MaktabatulSyuruq Ad-Dauliyah.

Farida, Ana. 2014. Pilar-Pilar Pembangunan Karakter Remaja; Metode Pembelajaran Aplikatif untuk Guru Sekolah Menengah. Bandung: Nuansa Cendekia.

Munawwir, Ahmad Warson. 2002. AlMunawwir Kamus ArabIndonesia. Surabaya: Pustaka Progressif.

Muntadi Syabāb Al-Mathariyah. 2012.

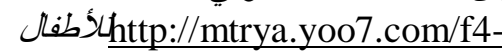
montada Online. Diakses pada tanggal 5 September 2016 pukul 08.15 WIB.

Musfiroh, Tadkiroatun. 2008. Memilih, Menyusun, dan Menyajikan Cerita untuk Anak Usia Dini. Yogyakarta: Tiara Wacana.

Nurgiyantoro, Burhan. 2013. Sastra Anak Pengantar Pemahaman Dunia Anak. Yogyakarta: Gadjah Mada University Press.

Kurniawan, Irwan. 2001. Kisah-Kisah Hewan dalam Al-Qur'an. Diterjemahkan dari buku asli berjudul: Qishash Al-Hayawān fi Al-Qur'an Al-Karim. Karya Ahmad Bahjat. Bandung: Pustaka Hidayah.

Kurniawan, Heru. 2009. Sastra Anak dalam Kajian Strukturalisme, Sosiologi, Semiotika, hingga Penulisan Kreatif. Yogyakarta: Graha Ilmu.

Riffaterre, Michael. 1978. Semiotic of Poetry. Bloomington London: Indiana University Press.

Zuchdi, Darmiyati dan Budiasih. 2001. Pendidikan Bahasa dan Sastra Indonesia di Kelas Rendah. Yogyakrta: Pas. 